\title{
Enslaved bodies, entangled sites and the memory of slavery in Cape Town
}

\section{The meeting of the dead and the living}

\section{Meghna Singh}

The aftermath of the brutal killing of George Floyd by a white policeman in Minneapolis has led to an ever-increasing effort towards anti-racist activism around the globe. Protests and political demands under the heading Black Lives Matter are being pursued all over the world. The surveillance and policing of historically marginalized and racialized groups and individuals, creating specific modalities of oppression and discrimination, has been deployed since the days of slavery. In South Africa, this racialized policing has continued from its apartheid days upholding segregationist policies against its nonwhite citizens. In 2018, during the busy holiday season over Christmas in Cape Town, Clifton beach made headlines nationally and internationally. However, this time, not for being a top beach destination for the holidaymakers but rather as a public site to be reclaimed by the local black population. The hash tag \#ReclaimClifton swept the news headlines as the organizers responded to private security guards asking black people to vacate the beach at 8 o'clock in the evening from 16 December onwards. The news stated,

Professional Protection Alternatives (PPA), a private security company hired by some residents at Clifton 4th beach, was accused of ordering people off the beach after 8pm last Sunday. Protestors slaughtered a sheep to exorcise the "demon of racism" after days of rising tension and claims about apartheid-style beach bans'.

(Mjo 2018)

The slaughtering sparked tensions at the beach, with animal rights activists opposing the act and the city's mayoral committee member for safety and security, JP Smith, stating that it was illegal to slaughter an animal in a public space without consent of the state government. Activists said that they were reminded of laws under apartheid where beaches were reserved for the exclusive use of whites. Their slogans stated, 'Never again will our beaches be segregated. We call on all our people to exercise their freedom of movement and access to our beaches' (IOL 2018). There are many demons that still haunt us in Cape Town and the act of slaughtering a sheep to reclaim a public space is a good starting point to discuss the history and pain of this country. 
Clifton beach has not always been a space occupied by rich white folk. It was in the news only a few years ago with the reporting of the discovery of the remains of a Portuguese slave ship that sank with 212 slaves on board in 1794, their hands and legs shackled as they drowned. The remains discovered in 2015 are part of an ongoing archaeological expedition (Boshoff et al. 2016). One of the principal archaeological investigators for the excavation of the São José shipwreck, Jaco Boshoff, states that there might be a possibility of a mass grave of the drowned slaves at Clifton beach, and they intend to conduct ground-penetrating radar to explore that possibility (Boshoff, personal communication, June 2018). Engaging with the given situation I ask the question: what if there is a discovery of a mass grave of drowned enslaved ancestors who were a part of the Middle Passage on their way to Brazil from Mozambique? What does that mean for the memory of slavery in the city that has a relationship of denial with its historic past? One does not think of 'forgiveness' and 'reconciliation' when we think of a nation oppressed under colonization. However, the end of apartheid saw the Government of National Unity set up the South African Truth and Reconciliation Commission (TRC) in 1995 as a restorative justice body to help citizens speak about human rights abuses through public hearings. Perpetrators of violence also gave testimonies and requested amnesty from both civil and criminal prosecution. The TRC operated under the tagline 'healing our nation', through truth and forgiveness. But 25 years later, what is its legacy? In her article, Pearl Boshomane asks the question, 'What has it done not only for South Africa as a country, but for ordinary South Africans?' (2016). Furthermore, Fanie du Toit argues that reconciliation was initially accepted by South Africans as an acceptance of their interdependence, with a strong commitment to justice and inclusivity. The post-apartheid leadership was mandated to build on these commitments in order to create a more just society over time. However, data from various public opinion surveys reveal that, despite important achievements, the government's failure to pay reparations, combined with state corruption and denial from the white community, have created increasing disillusionment with reconciliation (du Toit 2017). Furthermore, based on one of the documents from Wits University's Traces of Truth project (which preserves and archives documents relating to the TRC), Boshomane states that it erases the fact that racism was the root of apartheid, which downplays white supremacy, making it easier for systematic racism and white privilege to continue and thrive uninterrupted' (2016).

Given this background, what if the dead come to demand justice in a space occupied by privileged white people sunbathing and relaxing on the beach? Cape Town remains a racially divided city, a city of contrasts with extreme wealth and poverty co-existing. What happens to the artificial veneer of the city when the dead resurface and present the past to the people? This very scene provides the starting point for the installation art virtual reality project 
Container directed by Meghna Singh and Simon Wood that reflects on historical slavery by commenting on modern-day servitude. It places the audience on Clifton beach next to a white family as they witness the emergence of enslaved people pulling a container out of the ocean. Through a progression in historical time, it takes the audience on a journey into an endless maze of containers that reveal different forms of slavery: from following an enslaved man on a sugarcane plantation to watching a domestic servant in a colonial household to an Asian massage parlour and ending in a sweatshop using child labour in Bangladesh.

Container highlights the concept of 'European entanglements' as proposed by Elizabeth Buettner in the Horizon 2020 project ECHOES (European Colonial Heritage Modalities in Entangled Cities) methodological toolkit. She proposes that 'global flows of people (whether enslaved, indentured, or voluntary), goods, capital, and ideologies link European colonizing countries with overseas possessions and spheres of influence'. She further states that these 'complex colonial legacies remain central not only to post-colonial societies overseas but also echo resoundingly across Europe itself' $(2018,13)$. Inspired by Avery Gordon's writings on hauntings and ghosts (1997) and haunting and futurity (2011), the piece presents a meeting of the dead and living as a way to move on in the city. Gordon asks for a 'new sociology' and 'new forms of subjectivity' to bring about 'radical political change'. She proposes that we need to think beyond the limits of what is comprehensible. Inspired by her writings the project presents a strategy of imaging beyond the comprehensible to initiate healing and respect our ancestors. In her more recent writings, Gordon draws a parallel between racial slavery and modern capitalism in the United States. Furthermore, I borrow from Britta Timm Knudsen's concept of 'reframing', which she describes as the 'politicized mode of "re-emergence"". She states that

the colonial past tends to become de-politicized, packaged and consumed as just another "experience". A reframed colonial past can then, while boosting local, regional or even national economies, prevent awareness of, public debates on and actions relating to the past in question.

(Knudsen 2018, 41)

The same can be extended to South African society: the poorest are the people who suffered under colonialism and apartheid and form the underclass of society. Gordon asks us to be hopeful and borrows Kodwo Eshun's phrase 'inaugurating ones' to describe the present generation as not merely reactive subjects and to carry on emancipation work (Gordon 2011, 8). Focusing on the emancipation work that needs to be done not only in South Africa but globally, the work hopes to create an awareness that the present generation or the 'inaugurating ones' carry forward into the future while remembering and respecting the ancestors and providing justice in society. 


\section{Cape Town: a city of contrasts}

Cape Town remains one of the most racially divided cities in South Africa. The apartheid city planning continues to divide people along racialized identities. "White spaces" and "black spaces" remain separate through devices such as empty tracts of land - "buffer zones" between areas declared for different racial groups' (Shepherd and Murray 2007, 6). The contemporary face of the city for European and American holidaymakers is one of luxury amidst the unmatched beauty of the mountains and the ocean. It is a global cosmopolitan city, unique to the continent, dotted with world-class shopping malls, restaurants, and shopping. It is a city that denies its past like no other. Here I would like to quote archaeologist Nick Shepherd who states,

In the contested public sphere of the postcolony there is a certain kind of pleasure that is premised on institutionalized forgetting. Or we might put this differently, by saying that for those who can afford it the ultimate holiday lies in taking a holiday from history.

(Shepherd 2015, 104)

The history of slavery and apartheid is disavowed in the city and life carries on without social and economic restitution for the people who have suffered for decades. Furthermore, South Africa, as the space of a postcolony is described by Mark Fleishman, citing Achille Mbembe, as 'the multiple, contradictory moments of everyday life in Africa read against the persistent accretions of slavery, colonialism, apartheid and neo liberal forms of democracy' (Fleishman 2011, 8). He further states,

In this palimpsestuous time space, diverse urban worlds exist in the same territory filled with discontinuous fixtures and flows and odd juxtapositions and the past has an uncanny habit of inserting itself into the present in surprising and unexpected ways.

(Fleishman 2011, 8)

In the preface to his seminal text Children of Bondage, the historian Robert Shell explains the 'compelling similarities between slavery and apartheid in terms of legality, demographics, civil rights, and voiceless victims' (1994, xix$\mathrm{xx})$. Nigel Worden similarly writes of how slavery in rural and urban areas at the Cape encouraged racially based injustices, which were institutionalized by later policies across all areas of the country $(1985,4)$. Discussing presentday inequalities and their relation to the history of the country, I would like to borrow Anthony Bogues's (2010) idea of 'historical catastrophe', which suggests that an atrocious set of events set in the past are reproduced and recapitulated in new forms and contemporary disguises. Bogues suggests that it is not one historical event but a series of catastrophic events that condition our present. These traumatic events are recapitulated through time and their 
effects are borne on the bodies of their subjects. For Cape Town's victims of slavery and apartheid, this experience is recapitulated through their movement in the divided city where they continue to experience the segregation between the rich whites and the poor blacks. Writing about the history of colonialism and capitalism, Paul Gardullo states,

For far too many of us, the intimacy of individual lives are lost among or abstracted in the numbers. But they were, in the words of the curators at the Smithsonian Museum, inscribed in every coin that changed hands, each spoonful of sugar stirred into a cup of tea, each puff of a pipe, and every bite of rice.

(Boshoff et al. 2016, 4)

The recent student-led protests for decolonization of universities in 2015 and 2016 demonstrate that discontent amongst the 'born-free' generation is crystallizing and that South Africans are demanding redress for historical injustices. The Rhodes Must Fall and Fees Must Fall movements' demand for free higher education and the call for decolonization of the university curriculum showcases societal ruptures that have the potential to tear the contemporary fabric of South African society.

The project Container uses this idea of 'historical catastrophe' as a trope to present the journey from historical slavery to men, women and children caught up in modern-day servitude around the globe. Told through layers of the physical, virtual, constructed, and documented, a dark shipping container becomes the stage for true stories of people caught up in the system of modern slavery enabling our consumer society. In today's world, be it Cape Town, New York or London, there are thousands of people being exploited and work for nothing. It is not only the outsourcing of the production of commodities to the developing world that seeks cheap labour; the world's major cities are filled with invisible people forced into economic and domestic servitude. People have become commodities, which is the very definition of slavery: people as products. The 2017 Global Estimates of Modern Slavery report calculates that of 24.9 million victims of forced labour, 16 million are thought to be in the private economy, 4.8 million in forced sexual exploitation, and 4.1 million in state-sponsored forced labour including mandatory military conscription and agricultural work (ILO and WFF 2017).

Modern day slaves aren't captured, stocked like cattle on slave ships, and sold in public auctions. They are men, women and children lured into trafficking by the promise of a job and better life and then forced to work with little or no pay, or coerced to sell their bodies.

(Potenza 2014, 9)

The proliferation of contemporary slavery, despite legal sanctions against it, points to a greater need for global awareness, prevention, intervention, and advocacy. 


\section{A meeting of the dead and living as a way to move on}

Container is made in memory of the 212 enslaved men, women, and children who died in shackles when the São José Paquette de Africa sank in 1794. Those who survived were sold into slavery in Cape Town. Their descendants continue to live amongst us today. The work takes its inspiration from Avery Gordon's idea of 'haunting' that she describes as

a way in which abusive systems of power make themselves known and their impacts felt in everyday life, especially when they are supposedly over and done with (such as with transatlantic slavery, for instance) or when their oppressive nature is continuously denied (such as with free labor or national security).

(Gordon 2011, 2)

The possibility that there might be a mass grave of the drowned slaves from the São José or even the possibility of dead humans tied to shackles resting on the ocean bed just 100 metres from the beach makes their presence very much alive amongst us. Bringing Gordon's idea of 'haunting' into the space of Clifton beach, I would like to reiterate her point that 'haunting is not about invisibility or unknowability per se, it refers us to what's living and breathing in the place hidden from view: people, places, histories, knowledge, memories, ways of life, ideas' (Gordon 2011, 3). Gordon would describe the presence of the dead of the São José as a 'seething presence' of what is not there, what is past or lost or missing or simply not clearly visible (Gordon 1997, 22). Within this landscape and in order to feel and respect the presence of dead ancestors requires an 'experimental and embodied engagement' and I would like to suggest that this different engagement is what she describes as 'sensuous knowledge': sensuous knowledge is

receptive, close, perceptual, embodied incarnate ... it tells and it transports at the same time. Sensuous knowledge always involves knowing and doing. Everything is in the experience with sensuous knowledge. Everything rests on not being afraid of what is happening to you.

(Gordon 1997, 205)

Adopting the notion of a 'sensuous knowledge' in the conceptualization of Container allowed us to interact with the dead in a way that treats the dead with the respect they deserve. It allows us to present them as the embodiment of humans who finally deserve justice for the past. Looking at transatlantic slavery in her book Ghostly Matters (1997), she suggests that engaging with a ghost 'is about putting life back in where only a vague memory or a bare trace was visible to those who bothered to look' (Gordon 1997, 22). Writing about the significance of the ghost, she states that the ghost is important as it offers 
us future possibilities and a sense of hope, an opportunity to 'repair representational mistakes' and to create a 'counter memory for the future' (Gordon $1997,64)$. This is because a ghost is 'pregnant with unfulfilled possibility, with the something to be done that the wavering present is demanding' and ' $[t] h i s$ something to be done is not a return to the past but a reckoning with its repression in the present, a reckoning with that which we have lost, but never had' (Gordon 1997, 183). To engage with the idea that the ghost presents possibilities gives us a chance to respect the dead of the São José, not to disavow the dead and the past but to see it as an opportunity to create a space for healing. This is in line with the concept of 're-emergence' by Britta Timm Knudsen that states 'any emergence in the colonial field is also a re-emergence of past unacknowledged possibilities actualized at a specific time and moment' (2018, 1). The opening scene exhibiting the emergence of the dead from the ocean, walking on the beach, a space reserved for hedonistic pleasures of the rich invites an opportunity for people to engage with the ghosts. Gordon suggests that 'we must reckon with the ghost graciously, attempting to offer it a hospitable memory out of a concern for justice' $(1997,64)$.

In her more recent writing on 'haunting and futurity', Gordon (2011) draws a parallel between the legacy of slavery and US capitalism. This comparison is most pertinent in the contemporary political and social climate not only in the United States but globally. One can extend this parallel to South African society with the disparities between the rich whites and poor blacks in the racially divided city. Writing about the inheritance of racial slavery, she states,

Slavery has ended, but something of it continues to live on, in the social geography of where peoples reside, in the authority of collective wisdom in the veins of the contradictory formation we call New World modernity, propelling, as it always has, a something to be done. Such endings that are not over is what haunting is about.

(Gordon 1997, 139)

Borrowing from her suggestion, I would like to propose that the approach to end suffering and not just to witness it is 'to use haunting as the meeting of the dead and the living'. Gordon explains this methodology as:

With this particular conception of haunting, I was trying to develop a working vocabulary that registered and evoked the lived and living meeting, in their historical time, of the organized forces of order and the aggrieved person when consciousness of that meeting was arising, haunting, forcing a confrontation, forking the past and the future. I thought at that meeting point - in the gracious but careful reckoning with the ghost - we could locate some elements of a practice for moving towards eliminating the conditions that produce the haunting in the first place. 
How does the meeting of the dead and living work in the context of Cape Town? I would suggest in the post-colonial city, this meeting means paying attention to the fact that the ghosts need to rest in peace. It is not only about going back in historical time and trying to undo the past or apologizing for it but this methodology entails a promise to the dead about how we, as a people, shape the future. I propose that the present generation of South Africa, the 'inaugurating ones' (Kodwo Eshun's term), will bring about the transformation, do the emancipation work, the work that was promised but not followed through. Container hopes to contribute towards that awareness and generate a movement of action to demand change in society. It hopes to act as a trigger in inspiring a belief 'which has guided the worldwide movements to abolish slavery and captivity, colonialism, imprisonment, militarism, foreign debt bondage, and to abolish the capitalist world order known today as globalization or neo-liberalism' (Gordon 2011, 8).

\section{Container: witnessed the invisibilized-a response to the São José shipwreck}

Container is a collaboration between me and documentary filmmaker Simon Wood. We have directed and co-produced the project together. It has been co-produced by the non-profit organization Electric South, based in Cape Town. Electric South collaborates with artists across Africa in emerging storytelling by providing mentorship, production services, and funding to explore their worlds through immersive, interactive stories, including virtual and augmented reality and other digital media. Container will be presented as an installation experience at festivals, in public spaces and in museums around the world.

A few kilometres from Clifton beach where the remains of the São José Paquette de Africa wreck rest, cargo ships enter and leave Cape Town's busy port laden with thousands of shipping containers, their contents invisible, rarely discussed. Playing on the theme of the 'invisible', Container uses the hidden world of goods crisscrossing the globe in anonymous shipping containers to highlight the lives of the invisible millions that continue to be enslaved in new forms of modern-day slavery. The story of São José could have been told by creating a piece of work that commented on historical slavery but the creative strategy was to comment on contemporary slavery by linking the two and use the shipwreck as a starting point. The shipwreck, the invisible containers and contemporary economic servitude are the inspiration to craft this story.

Positioned at the intersection of virtual reality and installation art, the project invites people into a surreal maze-like world of containers, where they witness the truth behind the 'invisibilized'. The journey begins at Clifton beach, which hides the secret of the drowned slaves. The experience is about unravelling this secret. The viewer is taken on a cyclic journey that ends where it started. A mix of documentary and constructed reality, we witness black 
bodies trapped in an endless historical cycle of servitude. As part of the cyclic process, people emerge from water, take us on an unknown journey into the world of products and eventually sink into the ocean again. The underlying creative idea for the script is as follows: the ocean cannot speak but has ways to remind us of those who were chained, those who drowned, those immersed in new forms of economic servitude and those made invisible. It is not only the outsourcing of the production of commodities to the developing world that seeks cheap labour but also major world cities like Cape Town are filled with invisible people forced into economic and domestic servitude.

The set-up of the project includes a container as an installation experience, a container as a tactile virtual walkthrough experience built using photogrammetry and Unity using an Oculus VR (virtual reality) headset, and a container as a 180 degree video experience. The first container you enter is an installation. It looks pretty much like any other container, the walls are damp, and there is a strong smell of the sea. There is a bench in the room. Eventually someone will ask you to wear an Oculus VR headset, and you enter our second container, a virtual container. This begins your immersive virtual reality experience of being inside an identical container space generated using the photogrammetry and Unity technology. You can move around and explore the space but you become invisible to yourself: you can touch the walls without seeing your hands. It creates an embodied alienating feeling of entering a universe without being able to see your own body as part of the world. Once you sit down on the bench, it triggers a 180 degree video, allowing you to access the third container space. This is a mixture of documented realities filmed inside the Port of Cape Town and constructed realities based on testimonies from men and women we have met through our research of the past three years.

The film component of the project is divided into six scenes. The opening scene depicts Clifton beach with enslaved people emerging from the sea. The third container's floor is covered in thick sand. Oblivious to the container's surroundings, a white family laughs and jokes as if they are relaxing on a beautiful African beach. A large man sips a cool drink while his wife browses through a fashion magazine. Their children play in the sand. The boy builds sandcastles all around himself while the little girl meticulously digs herself into a hole. A large wave crashes, forcing the family and the viewer to look up. A two-dimensional image of Clifton beach appears on the container wall as if a film is being projected in the cinema. In the distance we see two black men emerging from the sea (Figure 13.1).

They strain as they pull heavy chains from the ocean. Focused on the task at hand, they move up the beach pulling the chains and leaving the twodimensional world behind as they enter the three-dimensional world of the container. They now stand next to the white children. Following them, we see four more black people emerging from the sea. The family looks on in shock as the men continue to pull the heavy chains. Attached to the chains, a container slowly rises from the depths. Suddenly, the container door violently 


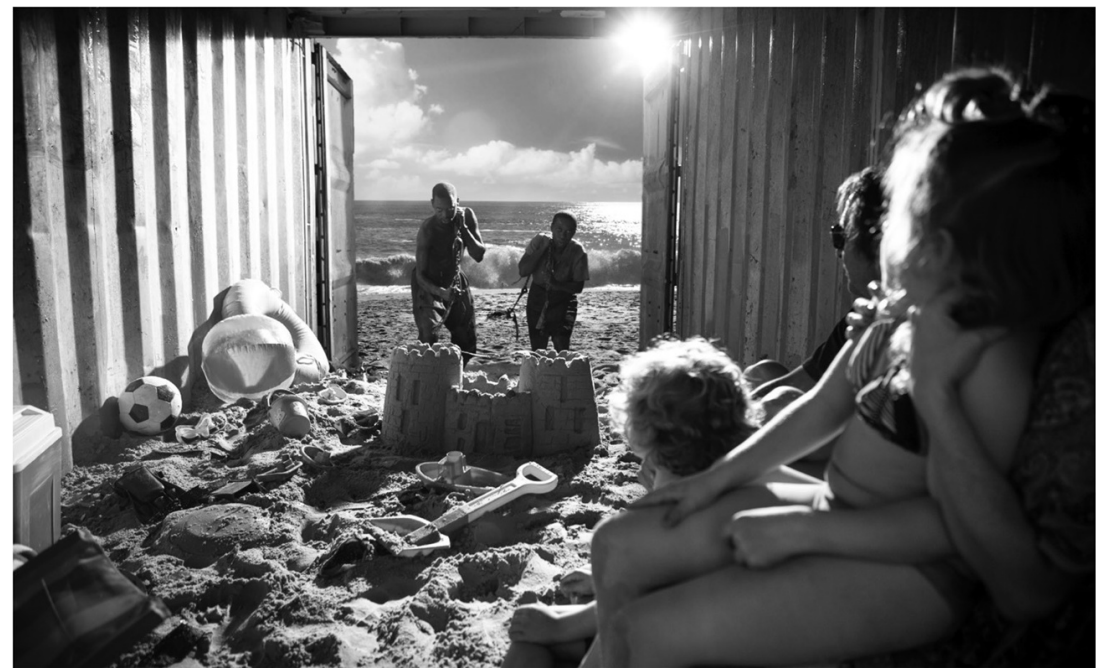

Figure 13.I Container, Meghna Singh \& Simon Wood (2021). Actors Shanda Shandu and Chuma Sopotela as the enslaved people pulling chains out of the ocean as a white family looks on. Film still from Container.

opens, the two black men drop the chains on the floor and then, with the white family, exit into the darkness.

The next scene is set in a dense sugarcane field where we follow a brutally wounded Mozambican man as he stumbles through the plantation. Sweating profusely, he enters the next container filled with soil and collapses into a hole. An Afrikaans maid buries the fallen enslaved man and unrolls a beautiful red carpet revealing a surreal colonial room ready for afternoon tea symbolizing 'domestic slavery' (Figure 13.2).

Scrutinizing the carpet for traces of dirt she sweeps vigorously. Dust begins to rise filling the container and blinking neon red lights slowly appear. The lights take shape into a garish red sign 'Full Body Massage'. Beneath the sign, bathed in red light, a large Dutch sailor lies on a table. A slight young Korean girl rubs his chest, working her way slowly towards his groin (Figure 13.3).

The lights get brighter and brighter engulfing the container in infinite blood red. Finally, the focus moves to 'children'. Four children sit on the container floor stitching logos onto Nike apparel. A cramped sweatshop in Bangladesh employs children who work long hours with little sleep. The light flickers off and on, we find ourselves in a rock quarry where a teenage black girl is breaking rocks with a hammer. We hear a loud thud and water starts gushing in from the roof of the container. She struggles then disappears into the depths (Figure 13.4).

Momentarily we are engulfed in the underwater stillness; products gently float in front of us. A diver's bright torch discovers us, blinding us. The 


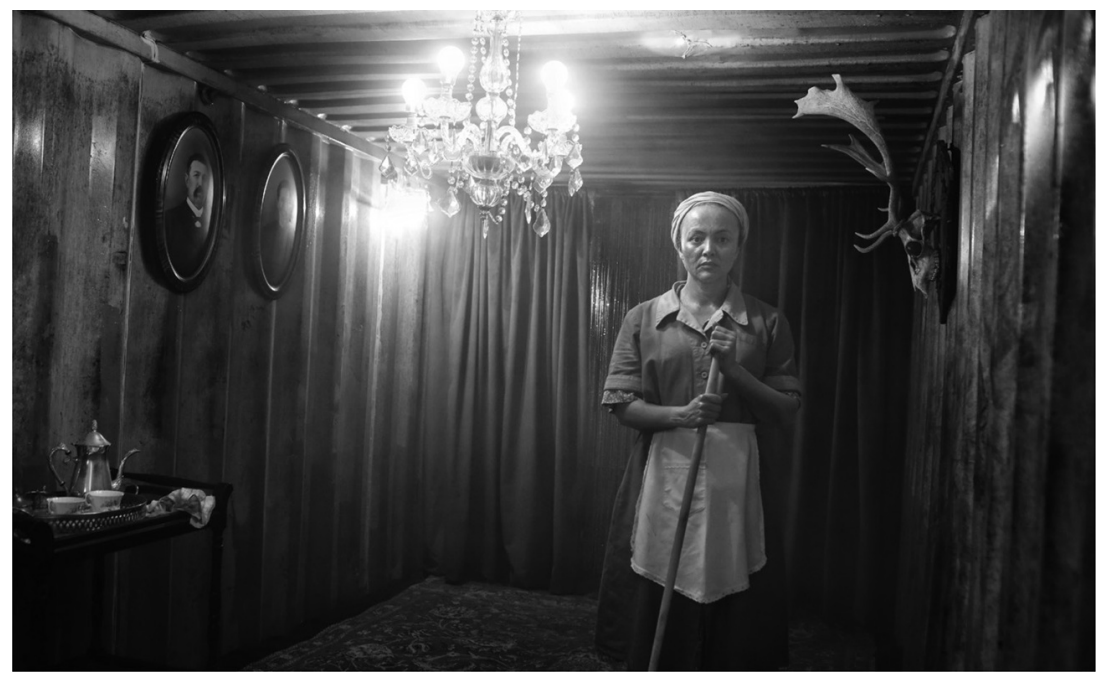

Figure 13.2 Container, Meghna Singh \& Simon Wood (2021). Actress Rehane Abrahams as a maid in a colonial household. Film still from Container.

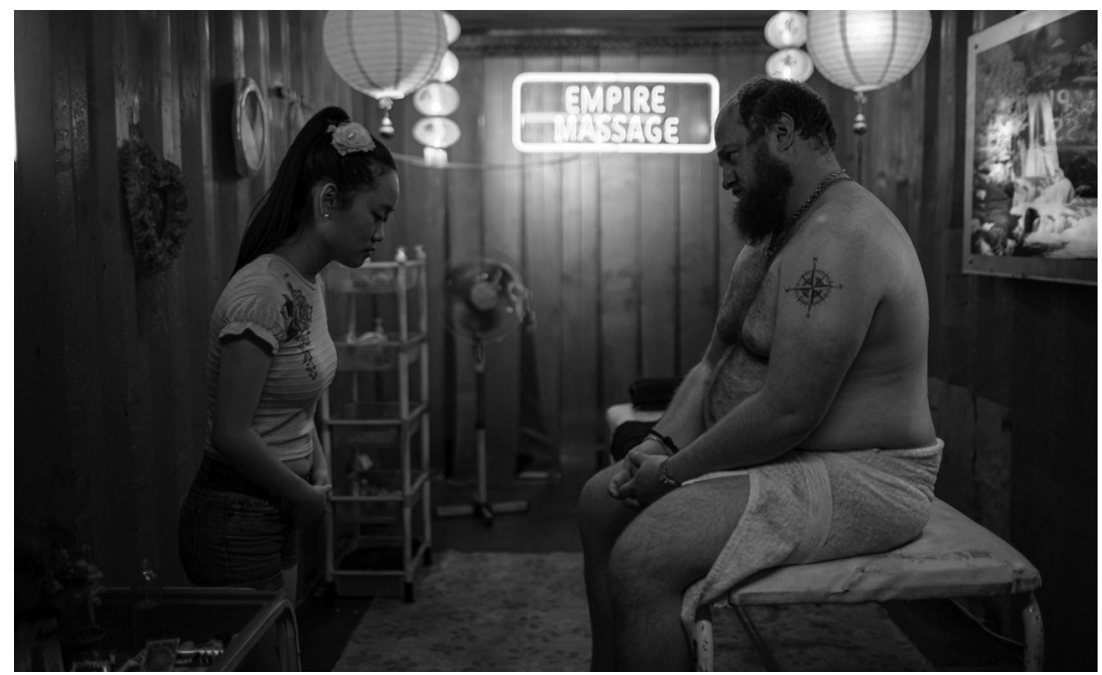

Figure 13.3 Container, Meghna Singh \& Simon Wood (2021). Actor Albert Pretorius as a sailor in a massage parlour. Film still from Container. 


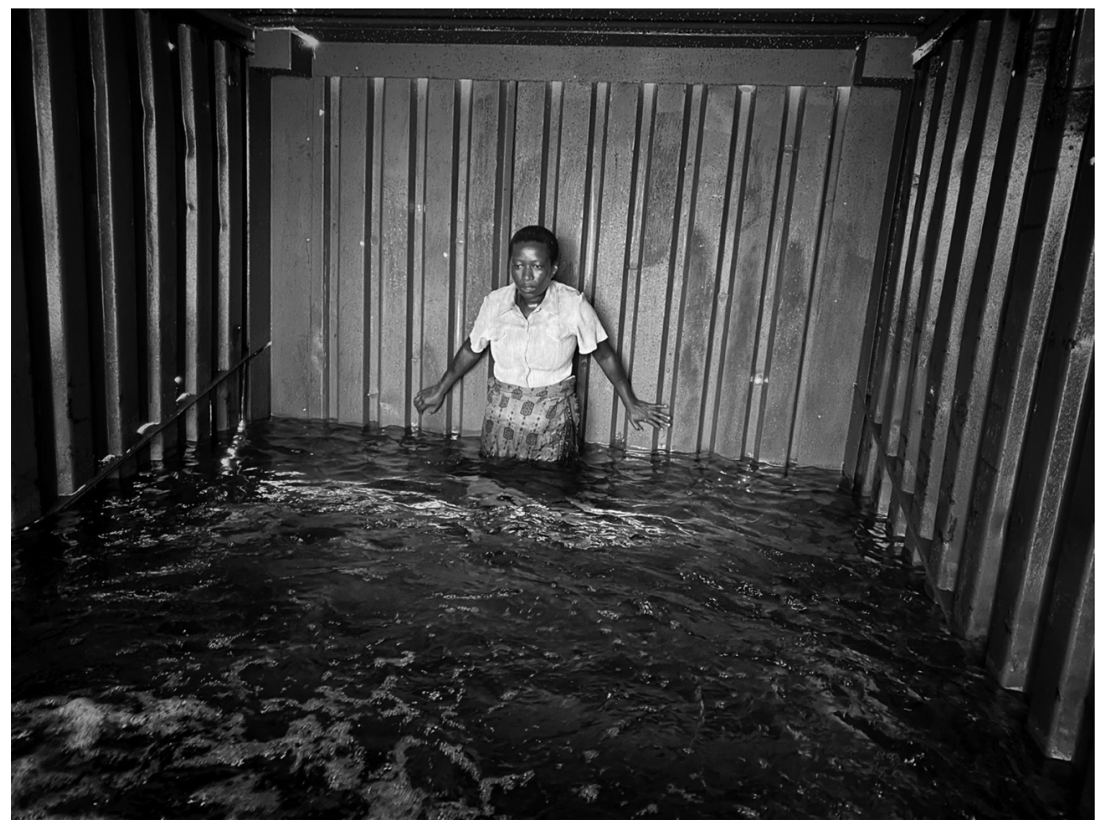

Figure 13.4 Container, Meghna Singh \& Simon Wood (2021). Actress Chuma Sopotela as the drowning woman. Film still from Container.

container's doors burst open revealing the white family staring back at us on Clifton beach. We look out of the door to our right and see a black man and a teenage boy standing outside holding chains as though they have just pulled the container out of the sea.

\section{Virtual reality, immersion, and a demand for change in society}

The concept of putting oneself in another's shoes to vicariously share experiences using media is not new. Even a print medium that presents no simulated sensory information can feel relatively realistic when an individual becomes deeply engaged. However, no other medium to date has been able to replicate the degree of realism that the Immersive Virtual Environment Technology offers.

(Ahn et al. 2013, 10)

Container is a virtual reality 180 degree three-dimensional film. We chose this format because of the close three-dimensional proximity it allows between the viewer and the subject $(50-80 \mathrm{cms})$. This enables a hyperreal tactility and viscerality of the constructed environments. By disrupting the comfort of 
one's personal space, we aim to facilitate an emotional engagement with the human condition that moves the audience. In addition to the element of proximity, we are working with one continuous long take enabling a seamless journey across time and space: from historical to modern-day slavery. As with every VR 180 film following 180 degrees of action is 180 degrees of darkness. In Container, this echoes the continuous darkness that the system of slavery has brought to our society.

The unique immersive characteristics of VR are an important part of understanding how this new technology compares to linear media in informing and engaging audiences on important social issues. The underlying artistic approach to the narrative is to create an experience that is surreal and seamless. We have focused on a seamless edit between scenes where one scene morphs into another, making it feel like a theatrical real-time experience. A great deal of attention has been paid to the art direction of the constructed realities to make them as real as possible. The six different scenes of modernday slavery have been thought through very carefully. We are working with method actors and rehearsing inside the confined dark space of the container to be able to demonstrate the emotions and stories of the people being represented. The idea of bringing the actors to the confined space of the container to represent real-life characters is a very different approach to filming characters at locations, which has been done previously in documentary filmmaking. There is no dialogue in the scenes that builds the tension within the characters as the scenes are to be experienced beyond language in an embodied way.

Taking the case of immersive environments further with the installation art virtual reality (VR) project Container, I will now discuss how the medium of the project proposes to push boundaries within academic research to sensitize the audience towards historical and contemporary slavery. Modern-day slavery is widespread across the globe, and we need a collective effort from diverse sources to create something impactful to make people realize their own participation in the system. We need to work across different sections of society from policy makers and politicians to the educators and the local public to take a step against this form of servitude.

Interpreting historical slavery in Cape Town and presenting it in its contemporary avatar, modern slavery, I researched and thought of a lot of effective immersive tools to stir a reaction in the audience, which should in turn demand justice, take responsibility, and hopefully take conscious action. There has been a case made for virtual reality to trigger emotions in people to take action. Feeling present in an experience generates feelings on the part of the viewer towards the characters depicted. A number of clinical studies, as well as a large body of anecdotal evidence, show that viewers have a stronger emotional response to a scene witnessed in VR than they do to one watched on a two-dimensional screen. Research has been conducted on the effect of embodied experience on people's attitudes. In the article 'The Effect of Embodied Experiences on Self-Other Merging, Attitude, and Helping 
Behavior' (Ahn et al. 2013), the authors propose that 'immersive virtual environment technology (IVET) provides users with vivid sensory information that allows them to embody another person's perceptual experiences'. From the conclusion of three experiments they conducted, they state:

Immersive virtual environment technology (IVET) can be used to enable individuals to easily and effectively experience the world from another person's point of view. With novel affordances such as multisensory inputs and naturalistic control of point of view, IVET allows for a literal demonstration of climbing into another person's skin to embody his or her experiences first hand. Vivid, multilayer perceptual information simulated by digital devices enable individuals to see, hear, and feel as if they were undergoing the sensory experiences in the physical world - what we call 'embodied experiences'. Using IVET, embodied experiences allow the user to experience the closest realization of the portal to enter another person's mind and body.

(Ahn et al. 2013, 8)

\section{Conclusion}

This chapter presents a new way to view the question of the memory of slavery in Cape Town. The potential possibility of discovering a mass grave of slave ancestors at Clifton beach not only makes us question how the remains of the dead have been dealt with in the past, but also asks us to think of future ways of viewing the system of slavery. Reflecting on the unfortunate forceful historical migrations of Africans to the New World, we have to imagine the journey of the Middle Passage, the torture and pain and the specific misfortune of the passengers on the São José. Virtual reality as a medium helps construct atmospheres that allow for a communication with the figure of the ghost through narrative and sound. This experience allows an engagement with concepts such as 'being and presence (over non being and absence)' (Buser 2017, 5). It also lends greater authority to the concept of 'hauntology' coined by Jacques Derrida in Specters of Marx, which Michael Buser likens to 'a philosophical and ethical destabilization of all manner of dualisms and universalizing totalities' (Buser 2017, 5).

Using this medium in the project Container, we hope it lets us consider how historical slavery has evolved into a much larger system of servitude around the world. The question remains: how do we propose to move forward in the city?

\section{References}

Ahn, Sun Joo, Amanda Minh Tran Le, and Jeremy Bailenson. 2013. "The Effect of Embodied Experiences on Self-Other Merging, Attitude, and Helping Behaviour." Media Psychology 16 (1): 7-38. 
Buser, Michael. 2017. "The Time Is Out of Joint: Atmosphere and Hauntology at Bodiam Castle." Emotion, Space and Society 25: 5-13.

Bogues, Anthony. 2010. Empire of Liberty: Power, Desire and Freedom. Dartmouth: Dartmouth College Press.

Boshoff, Jaco Jacques, Lonnie Bunch, Paul Gardullo, and Stephen Lubkemann. 2016. From No Return: The 221-Year Journey of the Slave Ship São José. Washington: Smithsonian Books.

Boshomane, Pearl. 2016. "20 Years after the TRC Hearings South Africa's Pain Persists." Times Live, Accessed 10 April. https://www.timeslive.co.za/sunday-times/ opinion-and-analysis/2016-04-10-20-years-after-the-trc-hearings-south-africaspain-persists/.

Buettner, Elizabeth. 2018. "European Entanglements.” ECHOES: European Colonial Heritage Modalities in Entangled Cities. Accessed 30 January 2021. https://keywordsechoes.com/european-entanglements.

Du Toit, Fanie. 2017. "A Broken Promise? Evaluating South Africa's Reconciliation Process Twenty Years On.” International Political Science Review 38 (2): 169-84.

Fleishman, Mark. 2011. "Cargo: Staging Slavery at the Cape." Contemporary Theatre Review 21 (1): 8-19.

Gordon, Avery F. 1997. Ghostly Matters: Haunting and the Sociological Imagination. London: University of Minnesota Press.

Gordon, Avery F. 2011. "Some Thoughts on Haunting and Futurity." Borderlands 10 (2): $1-21$.

International Labour Organization (ILO) and Walk Free Foundation (WWF). 2017. Global Estimates of Modern Slavery Report. Accessed 6 March 2021. https://www. ilo.org/wcmsp5/groups/public/@dgreports/@dcomm/documents/publication/ wcms_575479.pdf.

IOL. 2018. "ANC Slams Private Security Company for Ordering Citizens off Clifton Beach." Accessed 26 December. https://www.iol.co.za/news/south-africa/western-cape/ anc-slams-private-security-company-for-ordering-citizens-off-clifton-beach-18617023.

Knudsen, Britta Timm. 2018 "Re-emergence." ECHOES: European Colonial Heritage Modalities in Entangled Cities. Accessed 30 January 2021. https://keywordsechoes. com/re-emergence.

Mjo, Odwa. 2018. "Timeline: Rites, Racism and Rights Clash on Clifton's Pristine Sands." Times LIVE. Accessed 31 December. https:/www.timeslive.co.za/news/ south-africa/2018-12-31-timeline-rites-racism-and-rights-clash-on-cliftons-pristine-sands/.

Potenza, Alessandra. 2014. "21st Century Slavery." The New York Times Upfront. Accessed 17 March. https://www.scholastic.com/content/dam/teachers/migratedassets-not-associated-with-content/migrated-pdfs-and-other-files/upfront03171421stcenturyslavery.pdf.

Shell, Robert C. H. 1994. Children of Bondage: A Social History of the Slave Society at the Cape of Good Hope, 1652-1838. Johannesburg: Witwatersrand University Press.

Shepherd, Nick 2015. "Digging Deep: A Hauntology of Cape Town.” In Archaeology for the People: Joukowsky Institute Perspectives, edited by J. Cherry and F. Rojas, 96-107. Oxford: Oxbow Books.

Shepherd, Nick, and Noëleen Murray. 2007. "Introduction: Space, Memory and Identity in the Post-Apartheid City." In Desire Lines: Space, Memory and Identity in the Post-Apartheid City, edited by Noëleen Murray, Nick Shepherd and Martin Hall, 1-18. New York: Routledge.

Worden, Nigel. 1985. Slavery in Dutch South Africa. London: Cambridge University Press. 